\title{
The Youth and Land Access Challenges: Critical Reflections from Post-Fast Track Land Reform Zimbabwe
}

\author{
Clement Chipenda and Tom Tom
}

Land is a key resource that serves both productive and social purposes. Access to land enhances food and income security, and the attainment of the sustainable development goals that aim to reduce poverty and hunger (Kumeh and Omulo 2019; Rosset 2011). With an ever-growing youth population, struggles for land are expected to intensify in many parts of sub-Saharan Africa. ${ }^{1}$ Recent estimates suggest that between 2015 and 2025, about 11 million young people, for whom agriculture is or could be a substantial source of income (Yeboah and Jayne 2018), enter the labour market annually (Canning et al. 2015). Access to land, however, remains a challenge for many (AGRA 2017). Global agriculture is facing a crisis as younger and older generations struggle over resource allocation and use (Byamugisha and Ansu 2017; Chipato et al. 202O; White 2012, 2015). In some countries, land grabbing and corporate investment in largescale industrial farming have made land prices unaffordable and out of reach for the youth (White 2015). Moreover, political, gerontocratic and patriarchal biases, which the case of Zimbabwe exemplifies, are affecting access to agricultural land by youth and women (Chambati and Mazwi 2020; Mutopo 2011; Mutopo et al. 2014).

Despite an ambitious fast-track land reform programme (FTLRP) seeking to address colonial imbalances, the country faces severe challenges over access to land by the youth. ${ }^{2}$ Based on an empirical study in rural Goromonzi and Zvimba districts, we explore the formal and informal challenges that young people face in accessing agricultural land.

\footnotetext{
1 Estimates show that 41 per cent of sub-Saharan Africans are below the age of 15 and that 19 per cent are between the ages of 15 and 24 (UNDESA 2017).

2 For the purposes of this chapter, we use the 15-35 age bracket to refer to the youth. Zimbabwe identifies those in this age bracket as the youth ( $\mathrm{GoZ} 2013)$.
} 
Since 1890, unequal and repressive land policies have defined Zimbabwe's agrarian relations (Moyo and Chambati 2013). Against a backdrop of exclusionary and repressive laws (Gundani 2003; Martin and Johnson 1981), a protracted war of liberation dislodged colonial hegemony and led to independence in 1980. The postcolonial government faced the unenviable task of resolving the country's long-standing 'land question' (Mkodzongi and Lawrence 2019; Moyo 2013). At independence, 6ooo white farmers owned 15.5 million hectares compared with 4.5 million African farmers on 16.4 million hectares of land (Gundani 2003). The initial postcolonial land reform was unsuccessful with only 72,00o families being resettled in two decades against a target of 182,ooo set in 1982 (Moyo 1995). Only in 2000 did Robert Mugabe's government respond to pressure from liberation war veterans and local communities, and spearheaded a state-sanctioned, controversial, unplanned and polarizing FTLRP. In just over a decade, the programme led to the resettlement of 180,000 African households on 13 million hectares of land, thereby facilitating one of the biggest agrarian transformations in modern African history (Bhatasara and Helliker 2018; Moyo 2013).

While Zimbabwe's post-independence land reforms to some extent resolved the country's 'land question' (James 2015; Scoones 2015), scholars agree that only a few young people benefited (Scoones et al. 2019; Thebe 2018). Historically, land access constraints due to gerontocracy and, in the case of women, patriarchy, have been reported as prevalent in Zimbabwe's communal areas (CAs) and have persisted in contemporary times (see Mutopo 2011; Mutopo et al. 2014). This has raised what we term the 'contemporary youth land question'. It is premised on concerns that a growing youth population without land has emerged alongside a failing economy, high unemployment and less lucrative migration destinations locally, regionally and internationally. The youth are increasingly demanding their 'generational dividend' pertaining to political and economic space (Chipenda 2020a; Chipenda and Tom 2019). Within and beyond Zimbabwe, the central question is what role can the youth play in the agricultural transformation of postcolonial African countries?

This chapter is based on a study undertaken during the rainy season of late 2019 and early 2020, of two rural districts of Zimbabwe, Goromonzi and Zvimba. Both researchers were familiar with these areas, where they had been 
working for the previous six years. Goromonzi, which is in Mashonaland East Province, approximately 40 kilometres east of Harare, currently houses 2822 A1 (small-scale) and $846 \mathrm{~A} 2$ (medium-scale) ${ }^{3}$ farmers who were resettled on land previously owned by 122 white farmers on large-scale commercial farms (LSCF S). Also, 16 LSCF s and agro-estates were unaffected by the land reform (Chipenda 2020b). In Goromonzi, the respondents were selected from 13 former LSCF s, ${ }^{4}$ which have since been converted into small-scale A1 farms. They were also drawn from the CAs (former native reserves) of Chinyika, Rusike and Seke. Zvimba, which is in Mashonaland West Province in northern central Zimbabwe, is further divided into 35 wards and, before the FTLRP, had 718 LSCF $S$ and approximately 150,00o households under customary tenure (Murisa 2009: 21). Banket ward, where the fast-track farms of Dalkeith and Whynhill were selected for the study, lies approximately 95 kilometres to the northwest of Harare (Moyo et al. 2009). Prior to the FTLRP, the ward had 41 LSCF s, 16 of which were reconfigured into A1 farm units and 25 into medium-scale A2 plots.

Agro-ecologically, the two districts lie in regions with the country's highest average annual rainfall (between $75^{\circ}$ and $1500 \mathrm{~mm}$ annually) and the richest soils, making them prime areas for diversified agricultural production. They reflect Zimbabwe's varied agrarian and land tenure system. The accessibility of the districts and resulting opportunity to conduct a low budget study, their good rural-urban connectivity, high number of youth, and diverse range of rural livelihoods contributed to their selection for the study.

We used a predominantly interpretive and qualitative research paradigm to 'to better understand the land access challenges faced by the youth. Starting from a basic survey that yielded elementary quantitative information, we selected a cross-section of participants whose views and experiences are pertinent to an in-depth understanding of the youth's land access challenges. These included the children and grandchildren of the initial land occupiers, or those closely related to them in other ways; youth in nearby CAs; the initial land occupiers (or old generation of land beneficiaries); local traditional leaders and district administrators (or government officials now known as district coordinators), land officers and agricultural extension officers. During the

3 According to officially prescribed farm sizes under the FTLRP, A1 plots are smaller landholdings than A2 plots. For example, for region IIa (where the study was undertaken), A1 plots should be 15 hectares compared with A2 small-scale (30); medium-scale (200); large-scale (330); and peri-urban (2-30) (see Department of Lands 2001). However, in reality there are variations across and within agro-ecological regions. Unlike in $A_{1}$, access to the A2 scheme had to be supported by proof of capital/collateral.

4 These are Belmont, Eton, Dunstan, Warrendale, Xanadu, Brookmead, Manor Estate, Iddesleigh, Harveydales, Saratoga, Glen Avon, Northfield and Bellevue. 
interviews and focus-group discussions (FGD s), we invited our interlocutors 5 to suggest improvements. A review of scholarly articles and secondary sources complemented the primary data. It is, however, important to note that the two themes developed below are a mere selection and therefore not exhaustive.

In Goromonzi and Zvimba, all the current youth were still children when the FTLRP was implemented in the 20oos. Therefore, ownership of land units in both the smaller-scale A1 and medium-scale A2 schemes was minimal. Although some of them may have participated in informal land occupations alongside the war veterans (see Sadomba 2013), the majority were excluded from formal land allocations ${ }^{6}$ at the time. In relation to the A2 scheme, most youth did not qualify for formal allocation because of their lack of collateral, unless of course they could tap into social capital in the form of political connections with influential members of the ruling party. In both districts, it was noted that some beneficiaries of the FTLRP who are still alive are not ready to transfer land ownership (just yet) to the youth. They grant them access through a ceding process, in which they give land rights to a person of their choice. The Ministry of Lands, Agriculture, Water and Rural Resettlement oversees the whole process. Officials said that although they have transferred land to the youth using this method, it has been prone to contestations, conflicts and at times violence involving family members who disagree with the decisions made.

Since land title deeds are the only formal proof of land ownership (Moyo 2011; Moyo et al. 2009), in the two case studies we looked at who held the title deeds and the year in which the youth (the second generation of land beneficiaries) officially became landowners. Land title deeds to some extent guarantee security of tenure and the sense of ownership may increase commitment to agriculture. 'Offer' letters and A1 permits are the main documents required

5 District coordinators (2); lands officers (2); village heads (4); youth on fast-track farms (30); youth in nearby CA S (10); original land beneficiaries (40). Number of interviews and participants: 48 in-depth interviews were held with the first four categories of participants; Number of FGD s and gender composition: Two FGD s with ten participants each were held with the original land occupiers in every district. In Zvimba, five of the original occupiers involved are female, while in Goromonzi there were five young women accessing land who participated in the study. All methods and techniques were chosen for their suitability to the study.

6 In the two districts, informal land allocations took place in the early 2ooos. However, the participants explained that Dalkeith farm in Zvimba district was officially subdivided and occupied in 2000 (see also Murisa 2009: 249). 
to gain formal access to and ownership of land. For example, in Zvimba district, 67 per cent of the youth with official access to land had offer letters they had inherited from their parents, while in Goromonzi district, 100 per cent of the youth purposely selected for the study who have official access to the land either had an offer letter, or an A1 permit ceded by or inherited from their parents or allocated by the government. This information prompted further questions about official rights to land. First, most youth only inherited the offer letters and A1 permits after their parents had died, which may indicate that parents or guardians are unwilling to change ownership formally. Second, a culture of dominance by male elders, which is highly prevalent in Zimbabwe, and the unwillingness of some of the children or grandchildren of the initial beneficiaries of the land to recognize farming as a career (they see no future in it) reinforced the decision to cling to the land until death. Third, the government's timing in issuing A permits suggests that the land allocation went beyond the years between 2000 and 2008, which is often documented as the 'fast track' period. For example, in Goromonzi district, the government issued A1 permits to 13 per cent of the youth included in the study for land identified as vacant in 2016. On this point, the land officer clarified that the initial people to whom the land had been allocated had either accepted the offer or fled from the electoral violence experienced after 200o. Some had died without successors; others had just abandoned the land, and some land had become available through a state land rationalization scheme. Issuing land titles in 2016 was ZANU-PF's attempt at clientelist politics, as the party sought to swing the youth and other members of the electorate to its side in preparation for the elections of 30 July 2018. According to the lands officer in Goromonzi, few land titles were issued prior to this period, and the allocations had only been made after the available land had been identified. The politics of patronage is not new in Zimbabwe (see Sachikonye 2011).

In both districts, however, views converged around the fact that the post-FTLRP formal land allocations depended on having strong political connections, without which access to land was virtually impossible. In fact, the youth attending the focus-group discussions (FGDs) we organized were adamant about the importance of possessing political capital. This is hardly surprising given that studies on the FTLRP confirm electoral politics, patronage and the ruling ZANU-PF's history of using land provision as part of its hegemonic political project, especially in the strictly controlled resettlement areas (Chipato et al. 2020; Chiweshe 2011; Scoones et al. 2019; Zamchiya 2011). Another issue worth noting is that the traditional leaders, sabhukus (village heads), in Goromonzi see themselves as playing a pivotal role in allocating farms in the 'new' resettlement areas, despite having no legal entitlement to do so. Nonetheless, they recommend prospective beneficiaries to the local 
District Lands Committee and the local Lands Office. This is usually someone from their local community whom they know and can attest to having the 'right' political credentials, thus ensuring a consensus between the traditional leaders and the party supporting the application. It was abundantly clear that anyone who openly supported the opposition had a slim chance of being allocated land.

Research also revealed differences between youth in farming areas and in CAs. The majority of rural people in Zimbabwe live and practise subsistence agriculture in CAs, which the British colonialists created when dividing the land between Europeans and Africans, and marginalizing and degrading the latter in the process (see Dore 2009). The resettlement areas include the old resettlements the postcolonial government established soon after independence in 1980 and the new resettlements (also called fast-track farms) the FTLRP created (Chambati and Mazwi 2020). At FGD s, the youth opined that they had been dealt a blow by being born in CAs because the land there is scarce and the soil largely poor. They compared themselves unfavourably with the resettlement area youth whose parents, caregivers or relatives had managed to acquire land during the FTLRP. They felt that their counterparts were better off because they could inherit land by having been born into families with better land, thus creating enhanced opportunities and life chances. They observed a generational land transfer system in the FTLRP area, which was exclusionary and only benefited those who had been allocated land, thus creating new inequalities and differential development opportunities for young people. Our findings echo those of Dekker and Kinsey (2011) who noted differences between families in resettlement areas and cAs. The different land tenure systems, soil types, agricultural production activities, and social and institutional structures shaped the opportunities and life chances available to the youth. In the study areas, respondents criticized the negative attitude of the 'newly' installed traditional leaders (sabhukus) towards cA youth. They accused them of favouring those on the fast-track farms and stressed that future land allocations should give preference to them as they were traditionally disadvantaged.

Government officials participating in the study acknowledged that young people faced land access challenges, and that the problem, which affected the country at large, needed urgent resolution. However, they thought that the government had put adequate mechanisms and structures in place to address the youth's land needs, with registering on the national waiting list being a prerequisite to acquiring land. The completion of the second phase of the land audit and rationalization programme in fast-track areas in September 2020, and the promulgation of new farm-size regulations in February 2020, set out 
the future opportunities for youth to obtain land. The establishment of a Youth Desk in the Ministry of Lands, Agriculture and Rural Resettlement in 2018 charged with assisting youth with land and agriculture issues - was said to be another milestone in prioritizing youth concerns and demands. Of note was that the older generation, which had benefited from the FTLRP, felt that the failure of the youth to access land presented a serious problem and that the government should look at different ways of making it available to them. This included rationalizing land sizes by targeting those with landholdings that were too large, expropriating the remaining large-scale commercial farms, and allocating some unused state land to the youth. The elders, however, seemed determined to continue owning and controlling their land and were reluctant to share it with or hand it over to their children, but thought that the government should allocate them land elsewhere.

The implications of the various scenarios are not only that many youth have to overcome considerable hurdles to gain formal access to land, but also that only a few are able to access the fast-track farms. The situation is even more challenging for young women, as exemplified in Zvimba District, where none in the study sample owned land in their own right. The inheritance and ceding processes are both prone to contestation. This is because it is difficult to enforce traditional inheritance laws, especially if there is no will, and not all interested parties embrace the ceding processes. Furthermore, not all youth are interested in owning agricultural land: for some, natural resource exploitation and using the land for residential purposes is more appealing, while others do not want to practise agriculture but would rather participate in other parts of the agricultural value chain.

\section{5}

\section{Informal Access}

Youths may informally access land for agricultural and other purposes, such as establishing a home (musha), through family, household and community networks, and informal ways of transferring land ownership are commonplace, especially between spouses. Scholars in other study sites, for example Kwekwe District (Chibwana 2016) and Shamva District (James 2015), corroborate these findings. Informal access may also pertain to other groups, including farm workers (Sinclair-Bright 2019) and lessees (Mudimu et al. 2020). In both study sites, the youth discovered various ways, including informal social transfer and unauthorized plot subdivision, to access land: the initial land occupiers enabled their children and grandchildren to own land by subdividing the initial 
plot; facilitating the informal occupation of 'no man's land,' 7 and encouraging or negotiating land leasing on their behalf, especially where the family plot could no longer be subdivided. For example, at Dalkeith and Whynhill Ar farms in Zvimba District, the young participants all claim informal ownership of their parents' plots. Of these, 13 per cent are using leased land and 53 per cent were allocated an informal subdivision of the main plot by parents, guardians or other relatives on the basis of social transfer and the need to maximize land use.

Beneficial as these forms of youth access to land may be, they are also problematic. Unofficial social transfers, subdivisions or leasing to the youth or any other person are not legally recognized. However, because the government does not formalize land access in CAs, such transfers are not a problem, though accessing land through these means cannot guarantee access to loans for agricultural purposes. Overall, the participants found it difficult to get bank loans, even with the land ownership documents. The reluctance of the lending institutions arises from fear of non-payment due to limited land use and low production. Access to subdivided land relies on good relations; otherwise, the landowner can repossess. In the case of land leasing, failure to pay the leaser justifies the termination of what are often 'unwritten contracts'. Participants in FGD s stated that the continuing subdivision of plots is unsustainable; also, feelings of unfairness over the ratio used to subdivide the land often lead to conflicts between the usually young beneficiary and other family members. Moreover, the young respondents indicated that they curtail their ability to make decisions about land use, production, marketing and use of agricultural income.

These challenges were even more demanding for the young women in our study (see also Kazembe 1986; Mazhawidza and Manjengwa 2011; Mutopo 2011). Only one (out of five respondents) in the CA could claim land as hers. In Zvimba, two young women were allocated a piece of land, but that is still under the control of their father or male relative. Also, they were cultivating food crops for household consumption, whereas their male relatives grew commercial crops, the market price of which is markedly higher than the former. In the case of female youth, patriarchy, internal family dynamics and socialization present further obstacles to their independence.

Youths in Zvimba and Goromonzi districts experience various challenges in accessing agricultural land, which we explored along two axes - formal and

7 No man's land refers to land reserved for common grazing or unallocated or unoccupied in fast-track farms, CA s, and state land. 
informal. Field-based evidence shows that, despite their diversity, complexity and dynamism in understanding land access, the majority of youth have no direct access to, or own, land in either the fast-track farms or CAs. However, youngsters are indispensable to agriculture and other development activities and, prioritizing them for land allocations would be a first step towards ensuring agricultural success. However, that alone would not suffice: youth interested in farming, especially young women, should be appropriately supported and agriculture made 'classy' enough to attract them. This entails policy reorientation and a change of attitude. ZANU-PF and politicians in general need to go beyond politics and think of agrarian and youth development.

Land access challenges experienced by youth are not unique to Zimbabwe and are common in other African countries including Ghana, South Africa, Ethiopia, Tanzania, Namibia, Kenya and Zambia (Amanor 2010; Chinsinga and Chasukwa 2012; Djurfeldt et al. 2019; Jayne et al. 2012; Yeboah et al. 2019). This brings into perspective the challenges that Africa's agrarian future is facing in a context where agriculture and its associated value chains are considered key to economic transformation, development and poverty eradication (AU 2011). The urgent need to address youth land access challenges cannot be overemphasized.

\section{Acknowledgements}

We are grateful to the two anonymous reviewers whose insightful comments enriched the article. Special thanks also go to the editors of this volume as well as to Cyriaque Hakizimana, the coordinator of the Network of Young African Researchers in Agriculture (YARA) who facilitated our participation in the project. This study was made possible with funding from a small YARA grant awarded in 2019 by the David and Lucille Packard Foundation through the Institute for Poverty, Land and Agrarian Studies (PLAAS) at the University of the Western Cape. We also appreciate Professor Jimi Adesina and the University of South Africa (UNISA), who agreed to host us for the small YARA grant and Professor Issa G. Shivji of the University of Dar es Salaam for his mentorship.

\section{References}

AGRA (Alliance for a Green Revolution in Africa). 2017. Africa agriculture status report: The business of smallholder agriculture in sub-Saharan Africa. Nairobi:AGRA.

Amanor, K. S. 2010. "Family values, land sales and agricultural commodification in south-eastern Ghana." Africa, 80, 1:104-125. 
AU (African Union). 2011. Progress with CAADP: Partnership development issues in perspective. Draft input for preparation of the Economic Report on Africa, 2012. Addis Ababa: African Union.

Bhatasara, S. and K. Helliker. 2018. "Inside the land occupations in Bindura District, Zimbabwe.” African Studies Quarterly, 18, 1:1-17.

Byamugisha, F. K. and Y. Ansu. 2017. "Securing land tenure and access for the youth to modernize African agriculture." Paper presented at the Land Policy in Africa Conference in Addis Ababa, 14-17 November.

Canning, D., S. Raja and A. S. Yazbeck. 2015. Africa's demographic transition:Dividend or disaster? Africa Development Forum. Washington, DC: World Bank.

Chambati, W. and F. Mazwi. 2020. Towards a national gender-sensitive land policy in Zimbabwe: Issues for consideration. Harare: SMAIAS.

Chibwana, M. W. T. 2016. "Social policy outcomes of Zimbabwe's fast track land reform program (FTLRP): A case study of Kwekwe District." Doctoral thesis, University of South Africa.

Chinsinga, B. and M. Chasukwa. 2012. "Youth, agriculture and land grabs in Malawi." IDs Bulletin, 43, 6: 67-77.

Chipato, F., L. Wang, T. Zuo and G. Mudimu. 2020. "The politics of youth struggles for land in post-land reform Zimbabwe." Review of African Political Economy, 47, 163: 59-77.

Chipenda, C. 2020a. "The youth after land reform in Zimbabwe: Exploring the redistributive and social protection outcomes from a transformative social policy perspective." Canadian Journal of African Studies, 54, 3: 497-518. DoI: 10.1080/00o83968.2019.1648308.

Chipenda, C. 202ob. “The social and cultural dynamics of Zimbabwe's land reform programme on the 'new generation' of farmers: A transformative social policy perspective." African Identities. DoI: 10.1080/14725843.2020.1813553.

Chipenda, C. and T. Tom. 2019. "The generational questions after land reform in Zimbabwe: A social reproduction perspective." African Journal of Economic and Management Studies, 11, 3: 403-425.

Chiweshe, M. K. 2011. "Farm level institutions in emergent communities in post Fast Track Zimbabwe: Case of Mazowe District.” Doctoral thesis, Rhodes University.

Dekker, M. and B. Kinsey. 2011. "Contextualizing Zimbabwe's land reform: Long-term observations from the first generation." The Journal of Peasant Studies, 38, 5: 995-1019. Djurfeldt, A. A., G. Djurfeldt, E. Hillbom, A. C. Isinika, M. D. K. Joshua, W. C. Kaleng'a, A. Kalindi, E. Msuya, W. Mulwafu and M. Wamulume. 2019. "Is there such a thing as sustainable agricultural intensification in smallholder-based farming in subSaharan Africa? Understanding yield differences in relation to gender in Malawi, Tanzania and Zambia." Development Studies Research, 6, 1: 62-75.

Dore, D. 2009. The recovery and transformation of Zimbabwe's communal areas. Comprehensive Economic Recovery in Zimbabwe working paper series. Harare: UNDP Zimbabwe. 
GoZ (Government of Zimbabwe). 2013. Zimbabwe national youth policy. Harare: Ministry of Youth Development, Indigenisation and Empowerment.

Gundani, P. H. 2003. "The land question and its missological implications to the church." Missonalia, 31, 3: 467-502.

James, G. 2015. Transforming rural livelihoods in Zimbabwe: Experiences of fast track land reform 2000-2012 [doctoral dissertation]. University of the Edinburgh.

Jayne, T. S., J. Chamberlin and M. Muyanga. 2012. Emerging land issues in African agriculture: Implications for food security and poverty reduction strategies. Paper presented at the Stanford University's Global Food Policy and Food Security Symposium series, funded by the Center for Food Security and the Environment and the Freeman Spogli Institute for International Studies, Stanford, California, 12 January 2012.

Kazembe, J. 1986. “The women issue.” In Zimbabwe: The political economy of transition, 1980-1986, edited by I. Mandaza, 375-404. Dakar: CODESRIA.

Kumeh, E. M. and G. Omulo. 2019. "Youth's access to agricultural land in sub-Saharan Africa: A missing link in the global land grabbing discourse." Landuse Policy, 89. DOI: 10.1016/j.landusepol.2019.104210.

Martin, D. and P. Johnson. 1981. The struggle for Zimbabwe. London: Faber \& Faber.

Mazhawidza, P. and J. Manjengwa. 2011. "The social, political and economic transformative impact of the fast track land reform programme on the lives of women farmers in Goromonzi and Vungu-Gweru Districts." International Land Coalition, research report 8 .

Mkodzongi, G. and P. Lawrence. 2019. "The fast-track land reform and agrarian change in Zimbabwe." Review of African Political Economy, 46, 159: 1-13.

Moyo, S. 1995. The land question in Zimbabwe. Gweru: Mambo Press.

Moyo, S. 2011. "Land concentration and accumulation after redistributive reform in post-settler Zimbabwe." Review of African Political Economy, 38, 128: 257-276.

Moyo, S. 2013. "Land reform and redistribution in Zimbabwe since 1980." In Land and agrarian reform in Zimbabwe: Beyond white-settler capitalism, edited by S. Moyo and W. Chambati, 29-78. Dakar: CodesRIA.

Moyo, S. and W. Chambati 2013. "Introduction: Roots of fast track land reform." In Land and Agrarian reform in Zimbabwe: Beyond white-settler capitalism, edited by S. Moyo and W. Chambati, 1-28. Dakar: Code SRIA.

Moyo, S., W. Chambati, T. Murisa, D. Siziba, C. Dangwa, K. Mujeyi and N. Nyoni. 2009. Fast track land reform baseline survey in Zimbabwe: Trends and tendencies, 2005/o6. Harare: African Institute for Agrarian Studies.

Mudimu, G. T., Z. Ting, A. A. Shah, N. Nalwimba and A. M. Ado. 2020. "Land leasing in a post-land reform context: Insights from Zimbabwe." GeoJournal. DoI: 10.1007/ s10708-020-10219-y.

Murisa, T. 2009. An analysis of emerging forms of social organisation and agency in the aftermath of Fast Track Land Reform in Zimbabwe [Doctoral dissertation]. Rhodes University, South Africa. 
Mutopo, P. 2011. "Belonging and rural livelihoods: Women's access to land and nonpermanent mobility at Merrivale farm, Mwenezi district, Zimbabwe." Erdkunde, 6, 3: 197-207. DOI: 10.3112/erdkunde.2014.03.04.

Mutopo, P., J. Manjengwa and M. Chiweshe. 2014. "Shifting gender dimensions and rural livelihoods after Zimbabwe's fast track land reform programme." Agrarian South: The Journal of Political Economy, 3, 1: 145-161. DoI: 10.1177/2277976014530225.

Rosset, P. 2011. "Preventing hunger: Change economic policy." Nature, 479: 472-473. DOI: $10.1038 / 479472 a$.

Sachikonye, L. M. 2011. When a sate turns against its citizens: 6o years of institutionalised violence in Zimbabwe. Harare: Weaver Press.

Sadomba, Z. W. 2013. "A decade of Zimbabwe's land revolution: The politics of the war veteran vanguard." In Land and Agrarian reform in Zimbabwe: Beyond white-settler capitalism, edited by S. Moyo and W. Chambati, 79-121. Dakar: COD ESRIA.

Scoones, I. 2015. "Zimbabwe's land reform: New political dynamics in the countryside." Review of African Political Economy, 42, 144: 190-205.

Scoones, I., B. Mavedzenge and F. Murimbarimba 2019. "Young people and land in Zimbabwe: Livelihood challenges after land reform." Review of African Political Economy, 46, 159: 117-134.

Sinclair-Bright, L. 2019. "Ambiguous bonds: Relationships between farm workers and land beneficiaries after Zimbabwe's land reform programme." Journal of Southern African Studies, 45, 5: 927-944.

Thebe, Z. 2018. "Youth, agriculture and land reform in Zimbabwe: Experiences from a communal area and resettlement scheme in semi-arid Matabeleland, Zimbabwe." African Studies, 77, 3: 336-353.

UNDESA. 2017. World population prospects: The 2017 revision, key findings and advance tables (no. ESA/P/WP/248). New York: UNDESA

White, B. 2012. "Agriculture and the generation problem: Rural youth, employment and the future of farming." IDs Bulletin, 43, 6: 9-19.

White, B. 2015. "Generational dynamics in agriculture: Reflections on rural youth and farming futures." Cahiers Agriculture, 24, 6: 330-334.

Yeboah, F. K. and T. S. Jayne. 2018. "Africa's evolving employment trends Africa's evolving employment trends." Journal of Development Studies, 54, 5: 803-832.

Yeboah, F. K., T. S. Jayne, M. Muyanga and J. Chamberlin. 2019. Youth access to land, migration and employment opportunities: Evidence from sub-Saharan Africa. IFAD research series 53. Rome: International Fund for Agricultural Development.

Zamchiya, P. 2011. "A synopsis of land and agrarian change in Chipinge District, Zimbabwe." The Journal of Peasant Studies, 38, 5: 1093-1122. 